\title{
Pappaseng as a Philosophy of Community Life in South Sulawesi
}

\author{
Singkeru Rukka ${ }^{1} \quad$ Aminuddin Salle $^{2} \quad$ A.M. Yunus Wahid ${ }^{2} \quad$ A. Suryaman Mustari Pide ${ }^{2 *}$ \\ 1.Graduate School, Hasanuddin University, Indonesia \\ 2.Professor, Faculty of Law, Hasanuddin University, Indonesia
}

\begin{abstract}
Pappaseng as a philosophy of community life in South Sulawesi is a form of expression that reflects cultural values that benefit life. In a Pappaseng there is a great idea, noble thoughts, valuable soul experiences, and noble considerations of good and bad qualities. The noble values in a Pappaseng are packaged well in a concept with abstract meanings so that understanding those meanings requires certain approaches. Pappaseng is interpreted as a message, advice, advice, the will of the ancestors to their children and grandchildren, including the next generation which contains instructions, mandates, and convey moral proposals and values that must be carried out in order to live well.
\end{abstract}

Keywords: community, pappaseng, philosophy, South Sulawesi.

DOI: $10.7176 / \mathrm{JLPG} / 87-15$

Publication date:July $31^{\text {st }} 2019$

\section{Introduction}

The 1945 Constitution of the Republic of Indonesia (1945 Constitution) Article 32 paragraph (1) stipulates that "the state promotes Indonesian national culture in the midst of world civilization by guaranteeing the freedom of the people in maintaining and developing their cultural values". In the formulation of Article 32 paragraph (1) it implies the existence of an important role for culture in the formation of the identity of the people and the Indonesian people in particular, as well as for the modernity and progress of the nation in general. In this connection it was concluded that the development of Indonesian culture was the responsibility of the State, not only the government but also the community. Therefore a constitutional basis for state policy is needed, as stated in Article 32 paragraph (1) of the 1945 Constitution, to become a reference for the government and society in the development of Indonesian culture based on national pluralism, which is open to the development of world civilization and in accordance with values Pancasila.

The draft culture promotion law after being passed into law consists of 9 Chapters and 61 articles. It covers culture as an investment rather than a cost, an integrated cultural data collection system, the main ideas of regional culture, cultural strategies, a master plan for promoting culture, cultural trust funds, the use of culture, rewards and sanctions.

Culture is not only about dance and tradition, but also the value of noble characters that are passed down through generations to form the character of our nation. "Culture has become the root of our education; therefore, the Cultural Progress Law emphasizes protection, development, utilization and guidance so that Indonesian culture can grow resilient. Cultural development will be carried out dissemination, assessment, and increasing diversity of cultural objects". Finally in Progress Culture, the government invites the public to make use of cultural objects to build character, improve resilience, improve prosperity, improve Indonesia's position in international relations. ${ }^{1}$

The national movement for mental revolution is a movement throughout the Indonesian people along with the Government to improve the character of the nation into a better Indonesia. Many problems that occur in our country today, starting from the behavior of officials who enrich themselves, violations of Human Rights, to the daily behavior of the community. For example, do not want to queue and care less about the rights of others. However, behavior can be changed, mentality and character can be built. Therefore mental revolution is not an option but a necessity so that our nation can stand in line with other nations in the world. We can make Indonesia better by starting the Mental Revolution from ourselves, from now on.

As a form of strategy that gives direction for the creation of the welfare of the nation and state, the ideological basis of the mental revolution is Pancasila. With the three basic principles of Trisakti; 1 . Politically sovereign, 2. Self-reliance in the economic field, 3. Personality in the field of culture. This means that efforts to improve the nation's character through mental revolution from the beginning have clear corridors and culture is one of the main highlights.

Reformation, the general meaning is renewal which is a radical change for improvement in a society or state, up to the principle or fundamental thing with the aim of agrarian reform that is not separated from the legal objectives in general, namely justice, benefit and legal certainty. ${ }^{2}$ The Government of the Republic of Indonesia

\footnotetext{
${ }^{1}$ Further in relation to international relations can be read in a book written by Birkah Latif and Kadarudin, Pengantar Hukum Internasional, Pustaka Pena Press, Makassar, 2017.

${ }^{2}$ Aminuddin Salle, Hukum Pengadaan Tanah Untuk Kepentingan Umum, Total Media, Yogyakarta, 2007, p. 51-52
} 
in the 2015-2019 National Medium Term Development Plan (RPJMN) has 7 development missions, namely: 1. Realizing national security that is able to maintain regional independence, sustain economic independence by securing maritime resources and reflecting the personality of Indonesia as an archipelago. 2. Realizing an advanced, balanced and democratic society based on the rule of law. 3. Create non-active foreign policy and strengthen identity as a maritime country. 4. Realizing the quality of life of Indonesian people who are high, advanced and prosperous. 5. Realizing a nation that is competitive. 6 . Realizing Indonesia to be a maritime country that is independent, advanced, strong and based on national interests. 7 . Realizing a community that has a personality in culture

In Law No. 17 Year 2007 concerning the 2015-2025 National Long-Term Development Plan (RPJPN), ${ }^{1}$ 2015-2025 national development direction in chapter IV concerning the direction of long-term development, namely to realize a democratic Indonesia based on law. Increasing the realization of a society that has high legal awareness is continually improved by giving more access to all information needed by the community and access to the community for involvement in various national development decision making processes so that every member of the community is aware of and lives up to their rights and obligations. As a result, the behavior of Indonesian citizens will have a sense of belonging and law enforcement

Data from international surveys show that in good terms, the numbers for Indonesia tend to be low but in the bad case they tend to be high. For example, Transparency International data shows perceptions about the level of corruption in the public sector from 177 countries with 177 scores, Indonesia ranks 114 with a score of 32, this is below Ethiopia which is in position $111 .^{2}$ Indonesian people themselves feel anxious to see our morals, behavior, attitudes and mentality degenerate, intersect with each other on the highway, do not want to stand in line, lack respect for others. A series of Focus Group Discussions in Jakarta, Aceh and Papua conducted by the Transitional Home Mental Revolutionary Working Group also described the public unrest about our character as a nation.

The nation's irony about efforts to build morale with a mentality that is aware of the law has been sought by the government with various actions but that is also not enough to arouse public legal awareness. Community legal awareness is declining in theory and reality. What is faced in increasing legal awareness of the community is that Indonesian society is culturally and religiously composed of large groups and is plural in nature. ${ }^{3}$ So are facts about their needs and human interests. In meeting so many needs it is always under threat and may cause unexpected friction. Therefore what is needed is legal awareness. True legal awareness is an awareness of the rights and obligations of individuals, awareness of responsibilities as individuals and as members of society.

The reduced legal awareness of this nation has touched all elements and layers of society, from upstream to downstream or from the people to the authorities, from educated people to school dropouts. ${ }^{4}$ This research tries to explore the local cultural values in the form of Pappaseng which people have left to be a mandate, a will that must be obeyed and become an unwritten regulation and bind the supporting community.

Knowledge and level of education are no longer a measure of everyone's legal awareness because of the decline of human morals. ${ }^{5}$ On the one hand, the traditions and culture of the people in Indonesia that uphold good moral values such as manners and so on. But what is happening in society today is inversely proportional and it seems clear that moral damage has taken root in society. The impact of moral deterioration is very important for society because it is driven by the desire to be able to win alone, selfish by ignoring the interests of others so that moral values such as truth, justice, honesty and unity have begun to be ignored by some people. On the other hand values that are not commendable such as slander, taking the rights of others, lying, cheating and hurting others, have taken root in the community. The moral values that should have been guarded have now begun to wear off and some have been considered contrary to the modern understanding of society which is influenced by negative values brought through global understanding (globalism).

Moral damage has occurred everywhere and happens to anyone. The factors of moral deterioration today are actually many, among others, the most important are; 1). Lack of ingrained religious spirit in every person in society. 2). The condition of society is less stable, both in terms of economic, social, and political. 3). Moral education is not carried out as it should, both at home, school and society. 4). Poor household atmosphere. 5). The number of writings, images, broadcasts, arts that do not heed the basics and moral guidance. 7). Lack of guidance to fill spare time in a good way and leads to moral formation. 8). There is no or no guidance and counseling headquarters for children and youth. ${ }^{6}$

After knowing the impact and factors of moral damage that occur today, it can be concluded that moral

\footnotetext{
See http:/www.sanitasi.net/undang-undang-no-17-tahun-2007-tentang-rencana-pembangunan-jangka-panjang-nasional-tahun-20052025 html

${ }^{2}$ See http://www.ti.or.id/index.php/publication/2016/01/27/corruption-perceptions-index-2015

${ }^{3}$ See http://sudiknoartikel.blogspot.co.id/2008/03/meningkatkan-kesadaran-hukum-masyarakat.html

${ }^{4}$ See https://andinuzul.wordpress.com/2009/02/25/kesadaran-hukum-landasan-memperbaiki-sistem-hukum/

${ }^{5}$ See http://usmanunram.blogspot.co.id/2015/01/kesadaran-hukum.html

${ }^{6}$ See https://www.academia.edu/6150008/Peranan-Pendidikan-Agama-Dalam-Keluarga-Fachrudin
} 
improvement is a very important thing to be a common concern to find a solution. The current moral crisis cannot be underestimated and must be a shared responsibility, not blaming each other because the causes of moral crisis are very complex, although often some people bestow all these problems both directly and indirectly to educators, in this case in schools and teaching lecturers on campus. Without cooperation between all parties, of course, the problem of this moral crisis will be difficult to solve.

Moral values have many sources, one of them in ancient texts that can still be read until now like literature. ${ }^{1}$ These values can also be found implicitly from the behavior of some of the people they can orally from ancestors verbally. The excavation of regional cultural (legal) values as a concrete effort to support the government over the legal regulations made and provide opportunities for the growth of law in the regions.

Pappaseng as a form of local wisdom is a source of legal awareness that is very closely related. ${ }^{2}$ Legal awareness is a factor in the discovery of law, even said that the source of all law is legal awareness. In his opinion, the so-called law is only what meets the legal awareness of most people. So, laws that do not conform to the legal awareness of many people will lose their binding power.

Law is a concretization of the system of values that prevails in society. A condition that is aspired is the suitability between the law and the cultural value system. The consequence is that changes to the system of values must be followed by legal changes or on the other hand the law must be used as a means to make changes to the system of values. Thus it is evident that the problem of legal awareness is actually a matter of values. Awareness of law is abstract conceptions in man, about harmony between order and peace desired or deserved. ${ }^{3}$

There is still a lack of legal research regarding the culture of the community so that research on Pappaseng is good for appointment. The author observes that special legal research on Pappaseng has never been done, even though Pappaseng is a form of discourse on South Sulawesi's cultural products and is a cultural heritage of the past and is used as a philosophy of life for the people of South Sulawesi.

Pappaseng is in the midst of the Bugis people of Makassar, inherited from generation to generation, not only as a cultural symbol but also as a reflection of the attitudes, views and character of the Bugis people in the past. Therefore, an in-depth study is needed to reveal why at present Pappaseng seems to only be used as a display that is very pleasing to the eye and highly glorified and stored in an etalation but not maximally utilized to build a common benefit especially in improving the social life of the people of South Sulawesi in general and the Bugis community in particular. Based on this phenomenon, according to the author, Bugis people need to reflect on past life full of wisdom, but on the other hand there is a need to critically study to review the Pappaseng script by looking at various dimensions because it is not impossible that what is written in the Pappaseng script. If seen from the dimensions of the text ideologically or linguistically, there are things that always show relevance to the life of the social society of today's Bugis.

Legal awareness is an abstract that is difficult to know, ${ }^{4}$ bsecause it is difficult to assess everyone's legal awareness. It can only be seen from the way they act or in other words the legal obedience of everyone. How the person obeys the law. The higher the legal compliance of each person the greater the level of legal coverage of that person. Legal awareness and legal compliance determine the effectiveness or non-compliance of laws and regulations. The formation of a law-conscious society and obedience to law are the ideals of the norms that want a society that is just so that the joints of the culture of society will develop towards the creation of a system of society that respects each other. Making society aware and obeying the law is not as easy as turning the palm of the hand. Much has to be sought by the founder or thinker of this country to think about this.

Law is different from other sciences in human life, the law is different from other arts, sciences and professionals. Legal structures are basically based on obligations and not above commitments. Moral obligations to be aware of and the role of regulations form the characteristics of society. The moral obligation of the community for legal awareness, the obligation even though it forces the guarantee in the application or practice of the obligation is not absolute. ${ }^{5}$ Cultural pluralism that grows in society, norms and grow rapidly, moral obligation in solving problems with certain conditions. Awareness of the law is not the same as other social awareness. Legal awareness is an obligation that must be carried out and if not implemented, sanctions will arise. Not so with social awareness. When social awareness is not implemented or carried out, it is the social sanctions that apply to the community that become the judge. It is no exaggeration if awareness in the law tends to be forced.

Various literature is explained that it turns out that someone is aware of not breaking the law, other than due to deterrent factors or fear after witnessing or considering the possibility of sanctions being rewarded against him. If he is aware of the law, it can also be possible for someone to obey the law, because of other individual pressure or group pressure. And it is also possible for someone to obey the law for personal moral reasons. An

\footnotetext{
${ }^{1}$ See http://smanplusprovinsiriau.blogspot.co.id/2013/12/filologi-dan-penelitian-naskah-kuno.html

${ }^{2}$ See http://bugineseblogspot.co.id/2007/09/kearifan-iokaI-dalam-sastra-bugis.html

${ }^{3}$ Soekanto Soerjono and Mustafa. A. 1987. Sosiologi Hukum Dalam masyarakat, CV. Rajawali.

${ }^{4}$ See http://usmanunram.blogspot.co.id/2015/01/kesadaran-hukum.html

${ }^{5}$ See http://enymetabiogspotco.id/2011/OS/membangun-kesadaran-hukum-dan-ketaatan.html
} 
obligation to obey the law is a moral obligation of everyone and everyone believes from within that breaking a rule is wrong.

The culture of an area is very influential on the level of legal awareness of the community in the area. Culture is a way of life that develops and is shared by a group of people and is passed down from generation to generation. Culture is formed from many complex elements, including religious and political systems, customs, languages, tools, clothing, buildings and works of art. ${ }^{1}$ Language, as well as culture is an inseparable part of human beings so that many people tend to think of it as being genetically inherited.

As a legal state, people's lives cannot be separated from the rules that apply, both written rules and unwritten rules. Siri 'is a source of awareness that can lead to obedience to the life order including the applicable law. These rules must be fully obeyed. The existence of these rules is to create prosperity and justice in the community. If the rules are violated, they will get strict sanctions.

The progress of a nation can be seen from the level of legal awareness of its citizens. The higher legal awareness of the population of a country will be more orderly in the life of society and the state. Conversely, if the legal awareness of the population of a country is low, then the order of life becomes chaotic. In Indonesia there are still many people who violate laws or regulations. The regulations that have been agreed upon and written in fact are still being violated. This was not only among the government and society but also spread to agencies including educational institutions. Based on the explanation, the problem that will be examined in this paper is how is the concept of pappaseng as a philosophy of life? and how is the concept of the value of community legal awareness related to pappaseng?

\section{Research Method}

This type of research is socio-juridical using a statute and conceptual approach. ${ }^{2}$ The data used are primary data and secondary data collected through interviews, observations and documentation. The collected data is then analyzed qualitatively.

\section{Results and Discussion}

\section{A. Pappaseng As a Community Philosophy}

A. Suriyaman Mustari Pide $^{3}$ describes that the customary word comes from Arabic which means habit. The occurrence of the law originated from the human person which gave rise to personal habits and then imitated by others, so that gradually it became a custom that must apply to all members of the community so that it became customary law. Customary law is a translation of adatrecht. This nomenclature was the first time scientifically permitted by Snouck Hurgronje. Then in 1893, Snouck Hurgronje in his book entitled De Atjhers mentioned the term customary law as adat recht (Dutch language) which is to name a social control system that lives in Indonesian society. This term was later scientifically developed by Cornells Van Vollenhoven who was known as an expert in Customary Law in the Dutch East Indies (not yet being Indonesian). According to him adatrech $\mathrm{fx}$ is the best nomenclature that shows as an original legal system that is in accordance with the minds of the people who inhabit all corners of the archipelago, even though the nomenclature is not the naming of native Indonesians

The existence of customary criminal law in the community is because the law is a social reality and as a living law that is followed, and adhered to by indigenous peoples continuously, and preserved from one generation to the next. ${ }^{4}$ In Indonesia there are two systems of criminal law, namely the customary law system and the Western Criminal Law system (KUHP). The application of the rules of Criminal Customary Law still exists in several regions of the Republic of Indonesia, such as, in Sumatra, Sulawesi and Bali. ${ }^{5}$ Pappaseng/pappasang as a philosophy of community life in South Sulawesi is a form of expression that reflects cultural values that benefit life. In a Pappaseng there is a great idea, noble thoughts, valuable soul experiences, and noble considerations of good and bad qualities. The noble values in a Pappaseng are packaged well in a concept with abstract meanings so that understanding those meanings requires certain approaches, because it does not rule out the possibility that the meaning behind Pappaseng is situational.

Pappaseng literally comes from the basic word paseng which means message; while Pappaseng can be interpreted as an order. ${ }^{6}$ Some other references explain that Pappaseng is something that must be held firmly as a mandate or advice; a testament that needs to be known and heeded, as explained by Mattulada that paseng is a moral call to maintain the continuation of traditions inherited from generation to generation and to be the most

\footnotetext{
${ }^{1}$ See http://id.wikipedia.org/wiki/budaya

${ }^{2}$ Peter Mahmud Marzuki, 2005, Penelitian Hukum, Prenadamedia Group Jakarta, p. 35

${ }^{3}$ A. Suryaman Mustari Pide, Hukum Adat (dulu, kini dan akan datang), Jakarta: Pelita Pustaka 2009, p. 1-2

${ }^{4}$ Dara Indrawati, Eksistensi Hukum Adat Pidana Sebagai Hukum Positif Indonesia, Analisis Hukum Terhadap Beberapa Delik Kesusilaan

Putusan Pengadilan, Makassar: Pustaka Pena Press, 2016, p. 4

${ }^{5}$ Dara Indrawati, Perbandingan Hukum Adat Pidana, Makassar: Pustaka Pena Press, 2018, p. 5

${ }^{6}$ Said D.M., M. Ide, 1977. Kamus Bahasa Bugis Indonesia. Jakarta: Pusat Pembinaan dan Pengembangan Bahasa Depdikbud. p.150
} 
important tool that encourages the Bugis-Makassar people to faithfully maintain continuity of the panngadereng. ${ }^{1}$ In addition, Mattalitti stated that Pappaseng contained instructions and advice from ancient Bugis ancestors for their children and grandchildren to live their lives well in society. ${ }^{2}$ Sikki, and friends. Explain that the Pappaseng in Bugis is the same as the testament in Indonesian and synonymous with the word pangaja', advice, but these two words each have different nuances of meaning. ${ }^{3}$ Pappaseng more emphasis on moral teachings while the word pangajaq emphasizes more on an action that must be done or avoided.

Another explanation can be read in Punagi that Pappaseng is the will of parents to their grandchildren (many people) who must always be remembered as a mandate that needs to be obeyed and carried out on the basis of trusting themselves with a sense of responsibility. ${ }^{4}$ Nawawi also explained that Pappaseng was the advice of kings and wise men in the past which was estimated to be written at the beginning of the seventeenth century. ${ }^{5}$ Furthermore, it was explained that Pappaseng also contained historical ancestral events, old beliefs, habits; preserved customs known as pangadekeng which depict the Bugis life view which includes religious, social, cultural, state, legal norms and others. Another understanding was stated by Makkulau in an online writing that in principle Pappaseng was related to personality development and character formation, ${ }^{6}$ something very basic is understood that actions explain personal, never say harash, that never say lie, never do lnsincere, and never hurt others' feelings. It is not easy to know humans, but this Pappaseng teaches human recognition can be seen from his actions, or mappanessa knows. This understanding leads us to explore further the importance of Satan or "mutual humanizing", which means the same as Siparenngerangi, Sipanngajari, Sipaitai, or Sipakalebbi. Furthermore, it was also explained that Pappaseng taught about the use and improvement of human resources in carrying out daily life.

Thus, Pappaseng is interpreted as a message, advice, advice, the will of the ancestors to their children and grandchildren, including the next generation that contains instructions, mandates, and convey moral proposals and values that must be carried out in order to live a good life.

In South Sulawesi, each kingdom has smart people or smart people. The figure of this clever person is usually appointed as a royal official or advisor in a kingdom. In historical records, a number of regions in South Sulawesi have clever people, including titles; Kajao Laliddong in Bone, Arung Bila in Soppeng, Puang ri Maggalatung in Wajo, Grandma Mallomo in Sidenreng Rappang, To Maccaé ri Luwu, Boto Lempangan in Gowa. ${ }^{7}$ Based on these historical records, several Pappasengs were recognized, among others; Pappasenna Kajao Laliqdong, Pappasenna Arung Bila, and Pappasenna To Maccaé ri Luwu.

Pappaseng, like any wisdom or policy, has little or more always experienced a shift in value throughout its history. However, behind that there will undoubtedly also be some who do not change their value and do not conflict with the country's philosophy as a shared national value. Therefore, it is considered necessary to review and re-display regional texts, especially those in the form of Pappaseng. Thus, regional cultural values, especially the culture of the Bugis community can be maintained, especially cultural values which are considered to be still relevant to the circumstances and growth of today's society and society in future generations.

Based on this description it can be concluded that Pappaseng is a form of statement with language that contains ethical and moral values, both as a social system and as a cultural system of Bugis people that are passed down through generations to be carried out responsibly in order to live a better life and dignified.

\section{B. The Concept of Value of Community Legal Awareness Regarding Pappaseng}

The discussion of the meaning of important values in this description is mainly related to the legal value to get the true value essence, especially when it is associated with the search for the essence of value in Pappaseng.

Darmodiharjo and Shidarta in A.M. Yunus Wahid ${ }^{8}$ declare value which is a study of philosophical value (axiology) which is usually used to designate "abstract nouns" which can be interpreted as worth or goodness. Assessing means weighing or looking at, namely a human activity to connect something with something else, which is followed by giving a decision. The said decree states that something is of positive value (good, useful, etc.) or is of negative value (bad, detrimental, and so on) that is related to elements in humans in the form of physical, creative, sense, intention and trust. Thus, value can be interpreted as "the nature or quality of something that is beneficial to human life, both physically and mentally." Value is used as a basis, reason or motivation by

\footnotetext{
${ }^{1}$ Mattulada, 1995, Latoa: Suatu Lukisan Analitis terhadap Antropologi Politik Orang Bugis. Ujung Pandang: Hasanuddin University Press. hp 355

${ }^{2}$ Mattalitti, M. Arief. 1986. Pappaseng To Riolota. Jakarta: Depdikbud. p. 5

${ }^{3}$ Sikki, et.al. 1998. Nilai dan Manfaat Pappaseng dalam Sastra Bugis. Jakarta: Pusat Pembinaan dan Pengembangan Bahasa. Depdikbud. h.6

${ }^{4}$ Punagi, A.A. 1983. Pappaseng (Wasiat Orang Dahulu). Ujung Pandang: Yayasan Kebudayaan Sulawesi Selatan. p.5

5 Nawawi, Numaningsih, 2010. "Revitalisasi Falsafah Hidup Budaya Pappaseng” Serumpun Melayu Bugis-Makassar. Mengurai Kesempurnan Dunia Melayu dalam Konteks Hubungan Bangsa Serumpun lndonesia-Malaysia. Yogyakarta: Penerbit Ombak. p.552

6 Makkulau, M. Farid W., 2011. "Dimensi Sosial, Hukum, dan Agama dalam Pappaseng”. online. (http/lsosbud.kompasiana.com/2011/07/19/dimensi-sosial- Accessed 7 November 2011.

${ }^{7}$ Tangke and Anwar Nasyaruddin. 2007. Orang Soppeng Orang Beradab. Makassar: Refleksi

${ }^{8}$ A.M. Yunus Wahid, Aktualisasi Kearifan Lokal Menuju Hukum Lingkungan yang Responsif, Makassar: Pustaka Pena Press, 2011, p.73-77
} 
humans in behaving and behaving, both consciously and unconsciously. both tangible objects (material objects) and objects that are not tangible (inmaterial). This material value often has very high and absolute values for humans such as religious values. This value certainly can not be measured by measuring devices such as scales, meters etc. But it is measured by human mind.Values are the results of philosophical thinking that the owner sees as the most correct, wise and the best results, he is used as a foundation, reason or motivation for humans in all their actions, apart from the fact that there are people who consciously do something other than awareness of values for the same reason in too. Furthermore, it was stated that the implementation of these values was translated into normative measures. That is, if abstract values are to be used as guidelines in community life, they are formulated in a more concrete form in the form of norms, including legal norms (or as principles that inspire those legal norms). It is emphasized that the value is closely related to the interests of the subject that gives value, so that at that value there is always an interest. That is, each value contains ideals, namely ideas, feelings, inventions, and thoughts. Thus, talking about legal value means talking about legal ideals (rechtsidee) that have regulative functions. Values are closely related to ideals, desires, hopes and all things internal (inner) human considerations, so that they cannot be observed empirically. To be more useful in guiding human attitudes and behavior, this value needs to be concretized or formulated in certain symbols so that it is easily understood interpersonally. Its form is in the form of norms, including legal norms. The expressions and attitudes themselves are expressions of the values of the person concerned so that they can be traced in a certain way.

Alisjahbana in A.M Yunus Wahid ${ }^{1}$ "value has a special position as an element of culture". Culture is the incarnation of human cultivation, namely a mental pattern that contains life impulses that are basic, instinctive, feeling, with thoughts, volition, and fantasy. It is stated that human mind evaluates events and the surrounding objects, choosing the purpose and content of the culture, this process continues, determines and creates a variety of cultural objects. In human freedom assess and make choices from a large number of possibilities, the process of evaluating human mind is different, namely (1) theory assessment that is, if the objective is to objectively determine the identity of objects and events in the environment, which leads to the value of the theory; (2) economic valuation, leading to use value-economic value; (3) religious value; (4) aesthetic value; (5) Appraisal/value of power, and (6) Assessment-value of solidarity, value of power and value of solidarity related to norms of life $b$ together. This is where the legal values are contained. These values exist in human mind before meeting the outside world, the assessment process is a response to the outside world.

Furthermore, according to Alisjahbana as reviewed in A.M Yunus Wahid ${ }^{2}$ that in a shared life or community of values, it is not only the core of cultural objects, but the process of valuation and values is the "power" of the integration of the human person and society. In this case, the value of power becomes the highest norm or ethics of the entire configuration. both in personal form and in the form of society, the process of assessment and other values are more or less subject to goals, logic, and reality, personal ethics (autonomous ethics) centered on conscience or conscience, each person makes each person's behavior different with other personal behavior, the human/cultural community values and embodies values, namely the ethics of a heteronomous society.The ethics of this society manifest both in customs, customs and laws, this is what determines the behavior of individuals as members of society So in society, individuals have two traits, as autonomous strings and as individuals a member of a heteronomous society. In this case there is always "tension" between individual ethics and the ethics of society. It was stated, that the custom meant was not the same as custom or etiquette today. He is deeper and wider, everything called law is now included. Up to this point, it can be understood that the legal value is contained in the ethics of a heteronomous society.

From a number of expert opinions on A.M Yunus Wahid ${ }^{3}$ describes that, the value of environmental law can be traced through ideas, views or judgments, and the attitude of a person related to environmental law, both concerning substance and its application. Furthermore, he also said that humans themselves as a source of value, he is a seeker, inventor and developer of various values in his life.

Listening to the above view, related to the concept of value then by Darji Darmodiharjo and Shidarta in M. Syamsudin ${ }^{4}$ states that the concretization of values is the norm, including in this case is the legal norm. These legal norms then form a harmonious order in a harmonious order within a legal system, which functions as a system of social control, a means of resolving conflicts and as a means of renewing society.

Related to the problem of revealing the character of Pappaseng's legal value, the authors refer to Radbrouch in M. Syamsudin ${ }^{5}$ that there are three elements of legal values, namely justice, benefit and legal certainty. For justice, testing whether a rule has legal nature or not. The benefit is determined whether the content contains the truth, and whether legal certainty is determined whether it has validity or not.

\footnotetext{
Ibid, p. 78

${ }^{2} \mathrm{Ibid}$, p. 79

${ }^{3}$ Ibid, p. 90

${ }^{4}$ Darji Darmodiharjo and Shidarta in M. Syamsudin, Budaya Hukum Hakim Berbasis Hukum Progresif, Jakarta: Kencana Prenada Media Group 2012, p. 47

${ }^{5} \mathrm{Ibid}, \mathrm{p} .46-47$
} 


\section{Conclusion}

Pappaseng as a form of local wisdom is a source of legal awareness that is very closely related. Legal awareness is a factor in the discovery of law, even said that the source of all law is legal awareness. Moral values have many sources, one of them in ancient texts that can still be read until now like literature. These values can also be found implicitly from the behavior of some of the people they can orally from ancestors verbally. The excavation of regional cultural (legal) values as a concrete effort to support the government over the legal regulations made and provide opportunities for the growth of law in the regions. Pappaseng is interpreted as a message, advice, advice, the will of the ancestors to their children and grandchildren, including the next generation which contains instructions, mandates, and convey moral proposals and values that must be carried out in order to live life well.

\section{References}

A. Suryaman Mustari Pide, Hukum Adat (dulu, kini dan akan datang), Jakarta: Pelita Pustaka 2009.

A.M. Yunus Wahid, Aktualisasi Kearifan Lokal Menuju Hukum Lingkungan yang Responsif, Makassar: Pustaka Pena Press, 2011.

Aminuddin Salle, Hukum Pengadaan Tanah Untuk Kepentingan Umum, Total Media, Yogyakarta, 2007.

Birkah Latif and Kadarudin, Pengantar Hukum Internasional, Pustaka Pena Press, Makassar, 2017.

Dara Indrawati, Eksistensi Hukum Adat Pidana Sebagai Hukum Positif Indonesia, Analisis Hukum Terhadap Beberapa Delik Kesusilaan Putusan Pengadilan, Makassar: Pustaka Pena Press, 2016.

Dara Indrawati, Perbandingan Hukum Adat Pidana, Makassar: Pustaka Pena Press, 2018.

http:revolusimental.go.id

http://www.sanitasi.net/undang-undang-no-17-tahun-2007-tentang-rencana-pembangunan-jangka-panjangnasional-tahun-2005-2025.html

http://www.ti.or.id/index.php/publication/2016/01/27/corruption-perceptions-index-2015

http://sudiknoartikel.blogspot.co.id/2008/03/meningkatkan-kesadaran-hukum-masyarakat.html https://andinuzul.wordpress.com/2009/02/25/kesadaran-hukum-landasan-memperbaiki-sistem-hukum/ http://usmanunram.blogspot.co.id/2015/01/kesadaran-hukum.html https://www.academia.edu/6150008/Peranan-Pendidikan-Agama-Dalam-Keluarga-Fachrudin http://smanplusprovinsiriau.blogspot.co.id/2013/12/filologi-dan-penelitian-naskah-kuno.html http://bugineseblogspot.co.id/2007/09/kearifan-iokaI-dalam-sastra-bugis.html http://enymetabiogspotco.id/2011/OS/membangun-kesadaran-hukum-dan-ketaatan.html http://id.wikipedia.org/wiki/budaya https://ibeiboyz.wordpress.com/2011/12/10/makalah-meningkatkan-kesadaran-hukum-masyarakat/

M. Syamsudin, Budaya Hukum Hakim Berbasis Hukum Progresif, Jakarta: Kencana Prenada Media Group 2012.

Makkulau, M. Farid W., 2011. “Dimensi Sosial, Hukum, dan Agama dalam Pappaseng”. online. (http/lsosbud.kompasiana.com/2011/07/19/dimensi-sosial) Accessed 7 November 2011.

Mattulada, 1995, Latoa: Suatu Lukisan Analitis terhadap Antropologi Politik Orang Bugis. Ujung Pandang: Hasanuddin University Press.

Mattalitti, M. Arief. 1986. Pappaseng To Riolota. Jakarta: Depdikbud.

Nawawi, Numaningsih, 2010. "Revitalisasi Falsafah Hidup Budaya Pappaseng” Serumpun Melayu BugisMakassar. Mengurai Kesempurnan Dunia Melayu dalam Konteks Hubungan Bangsa Serumpun lndonesiaMalaysia. Yogyakarta: Penerbit Ombak.

Peter Mahmud Marzuki, 2005, Penelitian Hukum, Prenadamedia Group Jakarta.

Punagi, A.A. 1983. Pappaseng (Wasiat Orang Dahulu). Ujung Pandang: Yayasan Kebudayaan Sulawesi Selatan. Said D.M., M. Ide, 1977. Kamus Bahasa Bugis Indonesia. Jakarta: Pusat Pembinaan dan Pengembangan Bahasa Depdikbud.

Sikki, dkk. 1998. Nilai dan Manfaat Pappaseng dalam Sastra Bugis. Jakarta: Pusat Pembinaan dan Pengembangan Bahasa. Depdikbud.

Soerjono Soekanto dan Mustafa. A., Sosiologi Hukum Dalam masyarakat, CV. Rajawali, 1987.

Tangke and Anwar Nasyaruddin. 2007. Orang Soppeng Orang Beradab. Makassar: Refleksi. 